
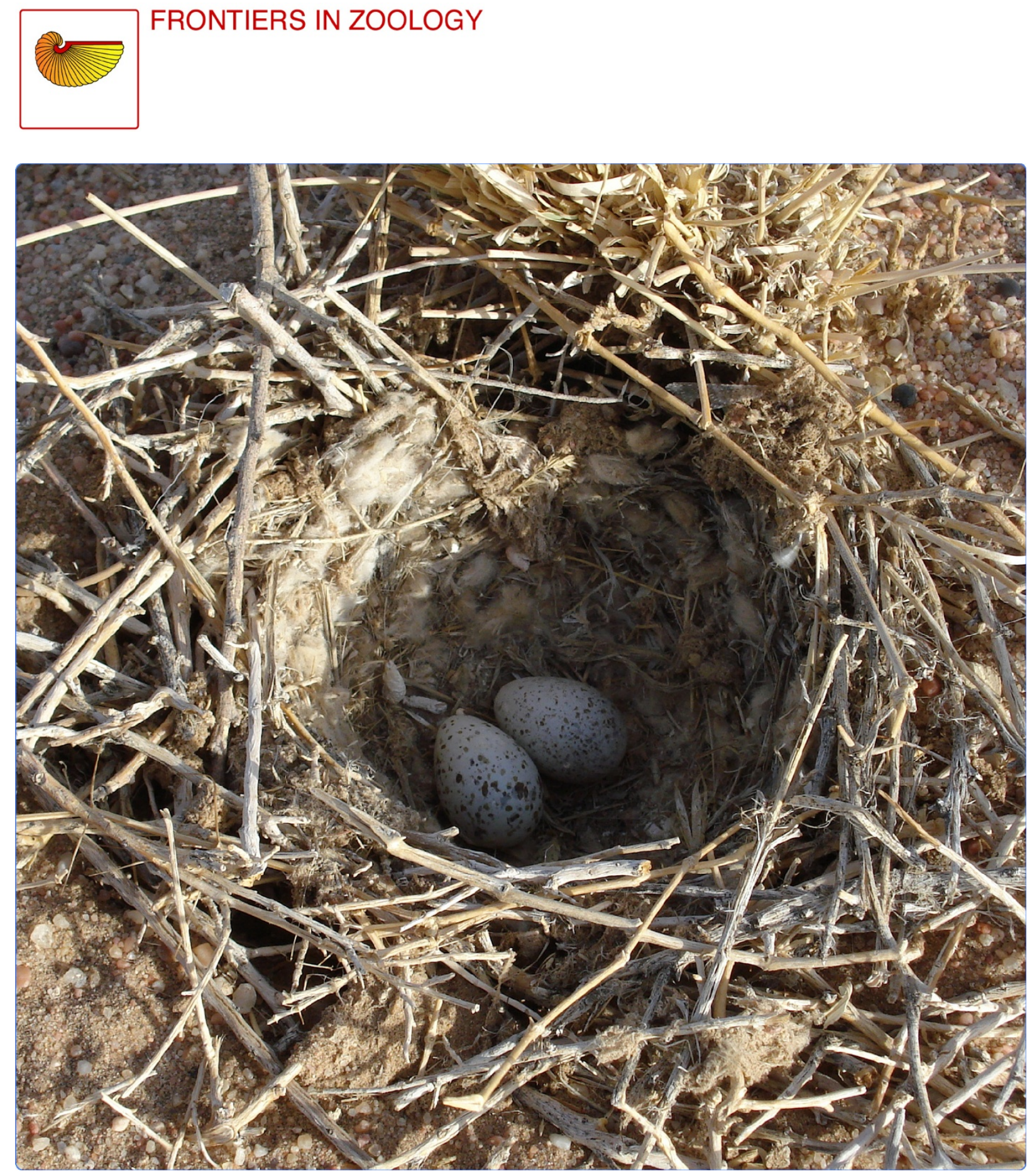

\title{
Are antimicrobial defences in bird eggs related to climatic conditions associated with risk of trans-shell microbial infection?
}

Horrocks et al. 


\title{
Are antimicrobial defences in bird eggs related to climatic conditions associated with risk of trans-shell microbial infection?
}

\author{
Nicholas PC Horrocks ${ }^{1,2^{*}}$, Kathryn Hine ${ }^{1}$, Arne Hegemann ${ }^{1}$, Henry K Ndithia ${ }^{1,3}$, Mohammed Shobrak ${ }^{4}$, \\ Stéphane Ostrowski ${ }^{5}$, Joseph B Williams ${ }^{6}$, Kevin D Matson ${ }^{1}$ and B Irene Tieleman ${ }^{1}$
}

\begin{abstract}
Introduction: All bird eggs are exposed to microbes in the environment, which if transmitted to the developing embryo, could cause hatching failure. However, the risk of trans-shell infection varies with environmental conditions and is higher for eggs laid in wetter environments. This might relate to generally higher microbial abundances and diversity in more humid environments, including on the surface of eggshells, as well as the need for moisture to facilitate microbial penetration of the eggshell. To protect against microbial infection, the albumen of avian eggs contains antimicrobial proteins, including lysozyme and ovotransferrin. We tested whether lysozyme and ovotransferrin activities varied in eggs of larks (Alaudidae) living along an arid-mesic gradient of environmental aridity, which we used as a proxy for risk of trans-shell infection.
\end{abstract}

Results: Contrary to expectations, lysozyme activity was highest in eggs from hotter, more arid locations, where we predicted the risk of trans-shell infection would be lower. Ovotransferrin concentrations did not vary with climatic factors. Temperature was a much better predictor of antimicrobial protein activity than precipitation, a result inconsistent with studies stressing the importance of moisture for trans-shell infection.

Conclusions: Our study raises interesting questions about the links between temperature and lysozyme activity in eggs, but we find no support for the hypothesis that antimicrobial protein deposition is higher in eggs laid in wetter environments.

Keywords: Antimicrobial, Aridity, Humidity, Egg albumen, Lark, Lysozyme, Ovotransferrin

\section{Introduction}

Microbial infection of eggs represents one of the main threats to the avian embryo during development [1], but the severity of this threat varies with environmental conditions. Microbial loads on eggshells and trans-shell infection rates are highest in cool, wet and humid environments. Consequently, declines in egg viability due to infection are greater and occur more rapidly in mesic and tropical environments than in drier, hotter, and more arid locations [2-6]. This might be because, relative

\footnotetext{
* Correspondence: nh415@cam.ac.uk

'Animal Ecology Group, Centre for Ecological \& Evolutionary Studies, University of Groningen, P.O. Box 11103, 9700 CC Groningen, The Netherlands

${ }^{2}$ Department of Zoology, University of Cambridge, Downing Street, CB2 3EJ Cambridge, UK

Full list of author information is available at the end of the article
}

to arid habitats, wetter environments are associated with increased primary productivity [7], including greater microbial abundance and diversity. For example, the abundance of microbes in soil, although strongly influenced by $\mathrm{pH}[8,9]$, is positively associated with precipitation [10-14], and soil microbes contaminate both birds and their eggs [15-17]. Bacterial loads in nests also correlate positively with precipitation [18], and birds in a temperate environment carry more microbes on their body and feathers than do related species in the desert [19]. Increased humidity can also encourage trans-shell infection, because in addition to promoting microbial growth on the eggshell [20-22], water is required to transport microbes through shell pores [23,24]. Conversely, the reduced moisture, increased solar radiation and temperature extremes associated with arid 
environments likely act to limit microbial assemblages [19,25-28] and microbial growth on eggshells [20-24]. Since the abundance of microbes on the eggshell is positively correlated with the probability of trans-shell infection [3,5], eggs laid in these settings may be at reduced risk of becoming infected.

To minimise infection by microbes, eggs possess physical barriers such as the shell and membranes, and chemical barriers in the form of antimicrobial proteins and peptides $[29,30]$. These barriers are set by the mother during egg formation, allowing her to transmit her experience of the wider environment to her offspring, thereby influencing offspring phenotype and survival [31,32]. Concentrations of antimicrobial proteins in the albumen relate to plasma levels in the mother [33] and are also related to her infection status $[34,35]$. Thus, mothers could adjust the level of antimicrobial defences they deposit in their eggs in order to optimise protection from trans-shell microbial infection [36-39]. Past studies of the antibiotic properties of eggs are few, and found no relationship between antimicrobial deposition and risk of infection within clutches $([36,38]$, but see [33]). This could indicate that the costs of producing antimicrobial proteins are insufficient to require differential deposition, at least within clutches. However, concentrations of antimicrobial proteins vary considerably among species [36] and variation in the risk of trans-shell infection may be greater for eggs laid in different environments than for eggs in the same clutch within an environment [3]. A recent study of chickens showed that individuals exposed to greater pathogenic load did modify some aspects of egg defences compared to those housed under more sterile conditions [39]. We hypothesised that if antimicrobial defences have evolved to match the risk of microbial infection [36-40] then concentrations of antimicrobial proteins in eggs should vary with those environmental conditions that predict the risk of trans-shell infection.

To test this hypothesis we collected eggs from larks (Alaudidae) along a gradient of environmental aridity that ranges from hyper-arid to mesic [41-43]. Larks are an ideal system for our purpose because different species inhabit environments with different macroclimates and show a range of well documented physiological and life history traits associated with these environmental differences [19,41-43]. Thus, our arid-mesic gradient encompasses larks from hot and cold deserts, temperate pastures and tropical grasslands. All lark species build open-cup nests in open habitats, which might make them more vulnerable to microbial contamination than eggs of cavity-nesting species ([44] but see [45]). Furthermore, all species commence incubation upon laying of the penultimate or last egg (see Additional file 1 for information on clutch sizes and onset of incubation), suggesting that the effects of early incubation in reducing risk of trans-shell infection are minimal in our study species $[4,5,21]$.

We measured concentrations of lysozyme and ovotransferrin, the two most abundant antimicrobial proteins present in the albumen [46]. Lysozyme catalyses the lysis of cell walls of gram-positive bacteria [47]. Ovotransferrin has bactericidal properties and binds iron to make it unavailable for bacterial growth [48]. The antimicrobial activity of both proteins might be influenced by the $\mathrm{pH}$ of the albumen, with more alkali albumen being more bactericidal [49]. Therefore we also recorded the $\mathrm{pH}$ of the albumen. We predicted that concentrations of lysozyme and ovotransferrin would be lowest in eggs from more arid environments (those that are hotter and/or drier) and higher in eggs from more mesic locations (those that are cooler, wetter, or more humid).

\section{Results}

Along our arid-mesic gradient, eggs laid in wetter environments did not differ in their lysozyme activity from those laid in drier locations (Figure 1a and Table 1). However, eggs laid in hotter environments had higher lysozyme activity than those laid at cooler sites (Figure $1 \mathrm{~b}$ and Table 1). Model averaging showed mean ambient temperature during the breeding season to be the best predictor of lysozyme activity (Table 2). Precipitation, albumen $\mathrm{pH}$ and our aridity index $\mathrm{A}_{\mathrm{M}}$ all explained little of the variation in lysozyme activity among species (Figure 1a and c; Table 2). Precipitation, temperature and aridity were all poor predictors of ovotransferrin activity (Figure 1d-f; Table 1) and most of the variation in ovotransferrin activity could be explained by albumen $\mathrm{pH}$ alone (Table 2). Lysozyme and ovotransferrin activities appeared negatively correlated with each other, but this relationship was not significant, either at the level of individual eggs (Spearman's rank correlation rho $=-0.15 \mathrm{p}=0.09$ ), or at the level of populations (rho $=-0.37 \mathrm{p}=0.20$ ).

\section{Discussion}

Immunological variation observed among individuals, populations and species might be a function of the risk of infection or disease, and variation in exposure of eggs to microbes has been suggested as one reason why birds might differentially deposit antimicrobial proteins into their eggs [36-40]. In related lark species, we found little evidence that climatic conditions associated with the risk of trans-shell infection could explain levels of antimicrobial proteins in eggs. We predicted that antimicrobial protein levels would be greater in eggs laid in wetter environments due to higher microbial abundances associated with increasing humidity $[10-14,18,19]$ and the importance of water for facilitating passage of microbes through the shell [23,24]. However, we found no relationship 


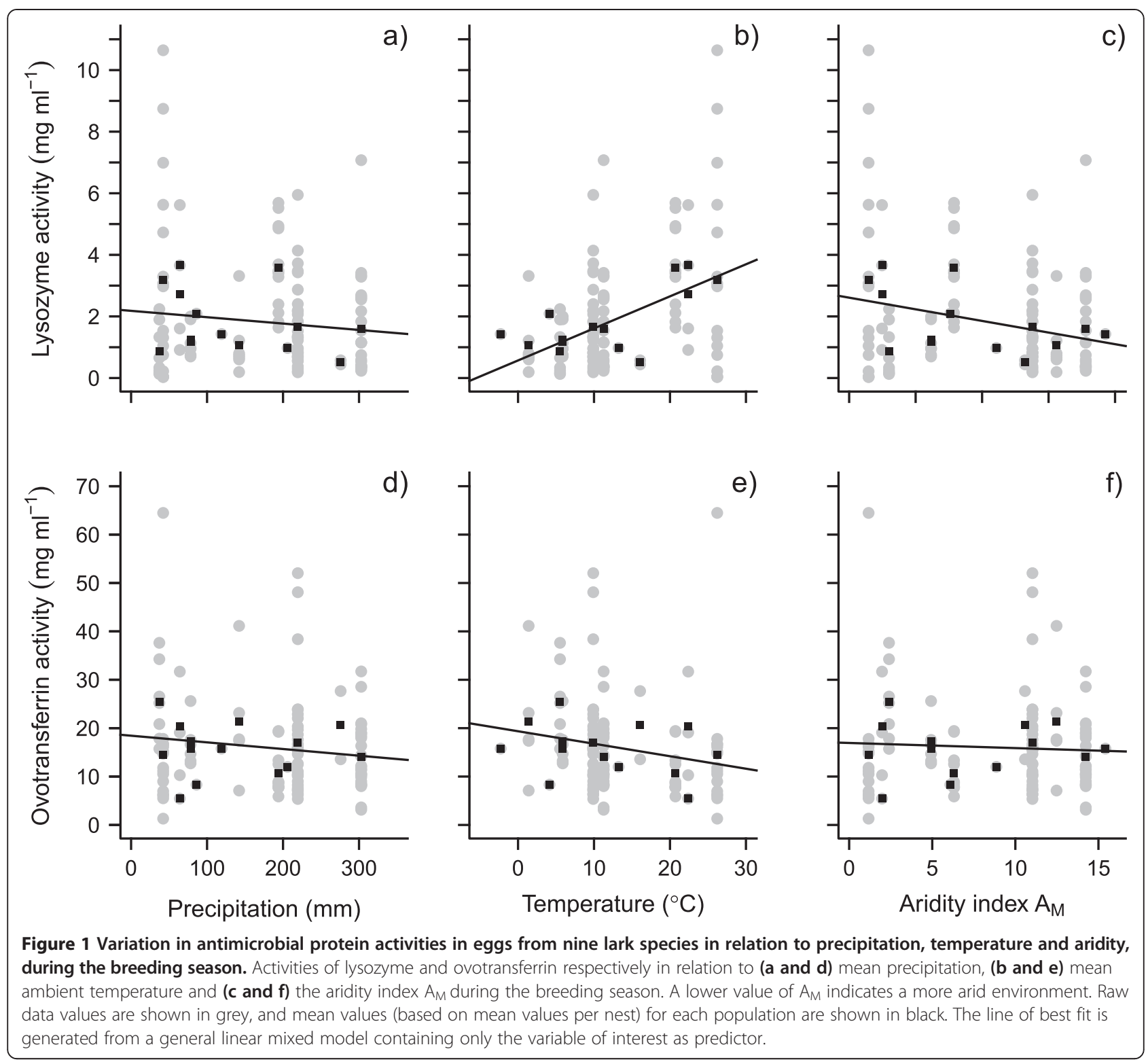

between antimicrobial activities in lark eggs and any of the climatic variables that related to moisture. This result appears at odds with the work of Cook et al. [3-5] who reported higher trans-shell infection rates in wetter environments. Although moisture on the eggshell is important for microbial growth [20,21], more recent studies have found that bacterial loads on the eggs of a temperate, cavity-breeding passerine show no relationship with precipitation [51], but do correlate positively with relative humidity in the nest [22]. This suggests that precipitation does not predict moisture on eggshells and is not directly linked to risk of infection (but see $[6,44,45]$ ). Given that brooding birds shelter their eggs from rain, and incubation counters the positive effects of water on trans-shell infection
[4,20-24], this is not surprising. Future work should focus on the nest microenvironment, as mechanisms of trans-shell infection at the level of the egg likely act differently to those functioning at the macro-climatic scale investigated in this study.

We found a positive correlation between lysozyme activity and temperature, but there was no effect of our aridity index $\mathrm{A}_{\mathrm{M}}$, or the interaction of precipitation and temperature, on antimicrobial protein levels. Thus, contrary to our prediction, eggs laid in hotter, more arid locations did not have reduced levels of antimicrobial proteins. It is difficult to consider the effects of temperature in the absence of moisture, but higher bacterial growth rates in warmer conditions might predict a positive association between temperature and antimicrobial defences. 
Table 1 Generalized linear models investigating the influence of climatic variables and $\mathrm{pH}$ on antimicrobial protein activities

\begin{tabular}{|c|c|c|c|c|}
\hline $\begin{array}{l}\text { Response } \\
\text { variable }\end{array}$ & Model formula & $k$ & $\triangle \mathrm{AICC}$ & $w_{i}$ \\
\hline \multirow[t]{12}{*}{ Lysozyme } & Temperature & 5 & 0.00 & 0.484 \\
\hline & Temperature + pH & 6 & 1.98 & 0.180 \\
\hline & Precipitation + Temperature & 6 & 2.05 & 0.173 \\
\hline & $\begin{array}{l}\text { Precipitation + Temperature + } \\
\text { Precipitation:Temperature }\end{array}$ & 7 & 3.78 & 0.073 \\
\hline & Precipitation + Temperature $+\mathrm{pH}$ & 7 & 4.18 & 0.060 \\
\hline & $\begin{array}{l}\text { Precipitation + Temperature }+\mathrm{pH}+ \\
\text { Precipitation:Temperature }\end{array}$ & 8 & 5.96 & 0.025 \\
\hline & $A_{M}$ & 5 & 10.90 & 0.002 \\
\hline & Null model & 4 & 11.39 & 0.002 \\
\hline & $\mathrm{A}_{\mathrm{M}}+\mathrm{pH}$ & 6 & 12.95 & 0.001 \\
\hline & Precipitation & 5 & 13.14 & 0.001 \\
\hline & $\mathrm{pH}$ & 5 & 13.57 & 0.001 \\
\hline & Precipitation + pH & 6 & 15.31 & 0.000 \\
\hline \multirow[t]{12}{*}{ Ovotransferrin } & $\mathrm{pH}$ & 5 & 0.00 & 0.334 \\
\hline & Temperature + pH & 6 & 0.29 & 0.289 \\
\hline & $\mathrm{A}_{\mathrm{M}}+\mathrm{pH}$ & 6 & 2.09 & 0.118 \\
\hline & Precipitation + Temperature + pH & 7 & 2.19 & 0.112 \\
\hline & Precipitation + pH & 6 & 2.22 & 0.110 \\
\hline & $\begin{array}{l}\text { Precipitation + Temperature + } \\
\mathrm{pH}+\text { Precipitation:Temperature }\end{array}$ & 8 & 4.42 & 0.037 \\
\hline & Precipitation + Temperature & 6 & 14.84 & 0.000 \\
\hline & Temperature & 5 & 16.14 & 0.000 \\
\hline & $\begin{array}{l}\text { Precipitation + Temperature + } \\
\text { Precipitation:Temperature }\end{array}$ & 7 & 17.07 & 0.000 \\
\hline & Null model & 4 & 17.44 & 0.000 \\
\hline & Precipitation & 5 & 17.99 & 0.000 \\
\hline & $A_{M}$ & 5 & 19.40 & 0.000 \\
\hline
\end{tabular}

Models are ranked by $\triangle \mathrm{AICC}$, which indicates the difference between each model and the model with the lowest AICc. The AICc weight, $w_{i}$, illustrates the relative likelihood of a model given the set of candidate models, normalised to sum to one. $k$ refers to the number of parameters in each model.

However, at high temperatures, such as those experienced at the extreme end of our aridity gradient, bacterial growth may be inhibited [52]. Current evidence for a relationship between egg lysozyme and temperature is equivocal $[53,54]$, and the small sample sizes in this study mean we must be cautious in interpreting the data. Nonetheless, this positive association between temperature and lysozyme activity is intriguing, not least because it is difficult to explain. Egg temperature is strongly influenced by incubation behaviour, which in turn can modify the risks of microbial infection [4,5,20-22], so links to ambient temperature might be expected to be weak. One possibility is that high lysozyme levels may be more important for eggs laid in hotter environments due to the physicochemical properties of lysozyme in eggs. Binding of lysozyme to the protein ovomucin determines albumen viscosity [55,56], which correlates positively with hatchability [57], but declines faster at higher temperatures [58]. Hence, high lysozyme levels in eggs laid in hotter environments might be unrelated to the antimicrobial functions of this protein.

Lysozyme and ovotransferrin showed weakly opposing patterns in relation to temperature, which could indicate a trade-off between these proteins, despite their negative correlation being non-significant. Lysozyme degrades gram-positive bacteria, while the iron-binding function of ovotransferrin makes it effective against a wide range of microbes. Since gram-positive bacteria tend to colonise egg contents less frequently [3-5], they may pose less of a threat to egg viability than other microbes, which could suggest that ovotransferrin is more valuable as a defensive protein than lysozyme. However, lysozyme can potentiate the activity of ovotransferrin and the two proteins may work in synergy, increasing their range of antimicrobial activity [59]. Thus, a balance between concentrations of lysozyme and ovotransferrin might be most effective in providing efficient, non-specific antimicrobial defence. This might also be preferable to simply increasing the amounts of either of these proteins in the egg, despite the fact that production costs may be minimal $[33,36]$. Increasing egg temperature by incubation provides an effective way of optimising antimicrobial activity [60], and other proteins and peptides also possess antimicrobial properties [30]. As more minor constituents of the egg, it may be easier to modify amounts of these other proteins in order to match egg antimicrobial defences to the risk of infection. In contrast, increasing amounts of lysozyme and ovotransferrin could be more difficult, since this might require a reduction in other aspects of albumen quality such as nutrition for the developing embryo. Experimental studies in chickens showing that egg white antimicrobial properties can be altered without changing lysozyme and ovotransferrin activities lend support to this idea $[39,61,62]$. Measuring the antimicrobial activity of whole albumen directly, in addition to concentrations of individual antimicrobial proteins, will yield additional insights. However, this will require further research to define suitable microbial challenges. Central to this work is the need to better describe and quantify the microbial assemblages of eggs and their microenvironments. Bacteria commensal with eggshells may be protective or pathogenic $[4,17,63]$ but there is currently little information from natural systems on which strains reduce hatching viability [64], and whether these strains are ubiquitous among species and nest environments. Abiotic factors such as $\mathrm{pH}$ and salinity, that are important in determining microbial biogeography $[8,9,65]$, should also be investigated for their role in shaping bacterial and fungal communities in nests and on eggs. Such knowledge is essential to developing a 
Table 2 Results of model averaging

\begin{tabular}{|c|c|c|c|c|c|}
\hline \multirow[b]{2}{*}{ Response variable } & \multirow[b]{2}{*}{ Model average parameters } & \multirow[b]{2}{*}{ Estimate (se) } & \multicolumn{2}{|c|}{$95 \% \mathrm{Cl}$} & \multirow[b]{2}{*}{ Relative variable importance } \\
\hline & & & Lower & Upper & \\
\hline \multirow[t]{5}{*}{ Lysozyme } & Temperature & $1.57(0.39)$ & 0.80 & 2.34 & 0.99 \\
\hline & Precipitation & $-0.13(0.37)$ & -0.85 & 0.58 & 0.33 \\
\hline & $\mathrm{pH}$ & $-0.15(0.35)$ & -0.83 & 0.53 & 0.27 \\
\hline & Precipitation:Temperature & $0.80(1.10)$ & -1.36 & 2.96 & 0.10 \\
\hline & $A_{M}$ & $-0.92(0.51)$ & -1.92 & 0.08 & 0.00 \\
\hline \multirow[t]{5}{*}{ Ovotransferrin } & $\mathrm{pH}$ & $-8.14(1.79)$ & -11.66 & -4.62 & 1.00 \\
\hline & Temperature & $-2.69(2.00)$ & -6.61 & 1.23 & 0.44 \\
\hline & Precipitation & $-0.78(2.00)$ & -4.70 & 3.15 & 0.26 \\
\hline & $A_{M}$ & $0.69(1.84)$ & -2.90 & 4.29 & 0.12 \\
\hline & Precipitation:Temperature & $-1.68(5.62)$ & -12.70 & 9.34 & 0.04 \\
\hline
\end{tabular}

Model average parameter estimates, standard errors (se), 95\% confidence intervals and relative variable importance, demonstrating the effects of climatic variables and $\mathrm{pH}$ on antimicrobial protein activities. Relative variable importance is the sum of all AlCc weights $\left(w_{i}\right.$ in Table 1$)$ over all models containing the explanatory variable of interest. Effect sizes have been standardized on two SD following Gelman 2008 [50].

better understanding of the risks of trans-shell infection in different environments and will be informative in explaining how birds modify the infection risks to their eggs.

\section{Methods}

\section{Antimicrobial protein assays}

We collected 124 eggs from nine lark species in 12 climatically distinct locations (Table 3 ). Four populations had low sample sizes (fewer than two eggs or nests per location; Table 3) but excluding these populations did not qualitatively alter our findings and so we present all results with these populations included. Eggs were collected on ice and dissected into constituent parts on the day of collection $(n=32)$ or where this was not possible, were stored whole at $-20^{\circ} \mathrm{C}$ and dissected later (0-98 days after collection, mean $=19$ days $)$. We recorded the $\mathrm{pH}$ of the albumen and used the quotient of embryo mass over total egg mass as a proxy for egg age. Seventy-six eggs contained no embryonic material, and of the remainder, only 13 were estimated to be more than four days old based on embryo mass (maximum estimated age $=$ seven days for one egg). Excluding eggs that showed any signs of embryonic development from our analyses did not change our main conclusions. Therefore all results are based on the entire dataset of eggs. The incubation period in all lark species is approximately 12 days [66], with incubation commencing upon laying of the

Table 3 Sample sizes, geographic origin and climatic variables for the eggs of the nine larks species used in this study

\begin{tabular}{|c|c|c|c|c|c|c|c|c|c|}
\hline Species & $n$ & nest $n$ & Latitude & Longitude & Altitude (m) & Country & $P(\mathrm{~mm})$ & $\mathrm{T}\left({ }^{\circ} \mathrm{C}\right)$ & $A_{M}$ \\
\hline Hoopoe lark Alaemon alaudipes & $18(8)$ & 9 & $22^{\circ} 14^{\prime} \mathrm{N}$ & $41^{\circ} 50^{\prime} \mathrm{E}$ & 1001 & Saudi Arabia & 42.23 & 26.22 & 1.17 \\
\hline Black-crowned finchlark Eremopterix nigriceps & $3(1)$ & 3 & $21^{\circ} 15^{\prime} \mathrm{N}$ & $40^{\circ} 41^{\prime} \mathrm{E}$ & 1489 & Saudi Arabia & 64.16 & 22.40 & 1.98 \\
\hline Crested lark Galerida cristata & $1(0)$ & 1 & $21^{\circ} 15^{\prime} \mathrm{N}$ & $40^{\circ} 41^{\prime} \mathrm{E}$ & 1489 & Saudi Arabia & 64.16 & 22.40 & 1.98 \\
\hline \multirow[t]{2}{*}{ Red-capped lark Calandrella cinerea } & $12(5)$ & 7 & $0^{\circ} 52^{\prime} \mathrm{S}$ & $36^{\circ} 23^{\prime} \mathrm{E}$ & 2038 & Kenya & 193.96 & 20.72 & 6.31 \\
\hline & $2(0)$ & 1 & $0^{\circ} 37^{\prime} \mathrm{S}$ & $36^{\circ} 28^{\prime} \mathrm{E}$ & 2456 & Kenya & 275.83 & 16.07 & 10.58 \\
\hline \multirow[t]{3}{*}{ Horned lark Eremophila alpestris } & $4(2)$ & 4 & $37^{\circ} 10^{\prime} \mathrm{N}$ & $72^{\circ} 53^{\prime} \mathrm{E}$ & 4084 & Afghanistan & 78.28 & 5.88 & 4.93 \\
\hline & $7(2)$ & 7 & $37^{\circ} 24^{\prime} \mathrm{N}$ & $73^{\circ} 30^{\prime} \mathrm{E}$ & 4122 & Afghanistan & 142.19 & 1.40 & 12.48 \\
\hline & $1(0)$ & 1 & $40^{\circ} 02^{\prime} \mathrm{N}$ & $83^{\circ} 09^{\prime} \mathrm{W}$ & 284 & USA & 206.05 & 13.24 & 8.86 \\
\hline \multirow[t]{3}{*}{ Hume's short-toed lark Calandrella acutirostris } & $3(0)$ & 3 & $37^{\circ} 11^{\prime} \mathrm{N}$ & $72^{\circ} 49^{\prime} \mathrm{E}$ & 4401 & Afghanistan & 78.28 & 5.88 & 4.93 \\
\hline & $9(6)$ & 7 & $37^{\circ} 25^{\prime} \mathrm{N}$ & $76^{\circ} 39^{\prime} \mathrm{E}$ & 4129 & Afghanistan & 37.20 & 5.53 & 2.40 \\
\hline & $1(0)$ & 1 & $37^{\circ} 18^{\prime} \mathrm{N}$ & $73^{\circ} 03^{\prime} \mathrm{E}$ & 3707 & Afghanistan & 119.09 & -2.28 & 15.42 \\
\hline Oriental skylark Alauda gulgula & $1(0)$ & 1 & $37^{\circ} 01^{\prime} \mathrm{N}$ & $72^{\circ} 41^{\prime} \mathrm{E}$ & 2802 & Afghanistan & 86.09 & 4.15 & 6.09 \\
\hline Skylark Alauda arvensis & $29(13)$ & 14 & $52^{\circ} 55^{\prime} \mathrm{N}$ & $6^{\circ} 15^{\prime} \mathrm{E}$ & 10 & Netherlands & 302.92 & 11.27 & 14.24 \\
\hline Woodlark Lullula arborea & $33(13)$ & 21 & $52^{\circ} 55^{\prime} \mathrm{N}$ & $6^{\circ} 15^{\prime} \mathrm{E}$ & 10 & Netherlands & 219.47 & 9.90 & 11.03 \\
\hline
\end{tabular}

$n$ : number of eggs (in brackets, number showing some degree of embryonic development); nest $n$ : number of nests. The climatic variables are mean breeding season values for precipitation $(P)$, temperature $(T)$ and the aridity index $A_{M}(P / T+10)$. A lower value of $A_{M}$ indicates a more arid environment. Altitude values are taken from Google Earth [67]. 
penultimate or last egg (Additional file 1). All eggs were collected during the period March-July 2007-2009.

We measured lysozyme activities by recording the rate of change in optical density (OD, $450 \mathrm{~nm}$ ) following addition of $200 \mu \mathrm{l}$ of a $1.0 \mathrm{mg} \mathrm{ml}^{-1}$ solution of Micrococcus lysodeikticus (M3770) in potassium phosphate buffer $(\mathrm{pH} 7.0,100 \mathrm{mM}$ ) to microplate wells containing $50 \mu \mathrm{l}$ of albumen. We used a spectrophotometric microplate reader (VersaMax, Molecular Devices, Sunnyvale, CA, USA) to record OD every ten seconds for 60 minutes at $25^{\circ} \mathrm{C}$, with each sample run at two dilutions (see Additional file 2 for more information). Standards of $50 \mu \mathrm{l}$ purified chicken egg white lysozyme (L6876; over the range 0.04-0.004 $\mathrm{mg} \mathrm{ml}^{-1}$ ) were also run in duplicate. We recorded the time (T75, in seconds) at which OD had decreased to $75 \%$ of the OD of a negative control (potassium phosphate buffer only). We then used a standard curve relating T75 to lysozyme concentration of the standards to calculate mean lysozyme activities $\left(\mathrm{mg} \mathrm{ml}^{-1}\right)$ of the two sample dilutions. We measured ovotransferrin activities $\left(\mathrm{mg} \mathrm{ml}^{-1}\right)$ as described in [68], using $10 \mu \mathrm{l}$ of albumen instead of plasma. All chemicals were purchased from Sigma-Aldrich (St Louis, MO, USA).

\section{Climatic data and indices of environmental aridity}

We obtained high-resolution $(0.5 \times 0.5$ degree - approximately $55 \times 55 \mathrm{~km}$ ) gridded data on climatic variables for the period 1901-2009 from the Climatic Research Unit time series dataset (CRU TS 3.1) [69]. Seasonal variation in environmental and bird-derived microbial abundances [70] suggests that climatic conditions immediately preceding and during egg laying and incubation might have the most influence on the potential for trans-shell infection. Therefore, for each species and location we calculated mean values for precipitation $(\mathrm{P}, \mathrm{mm})$ and temperature $\left(\mathrm{T},{ }^{\circ} \mathrm{C}\right)$ for the period covering the month prior to that in which the first egg was laid, up to and including the month in which the last egg was laid. We used these climatic variables to calculate an index of aridity, de Martonne's aridity index $A_{M}(P / T+10)$ [71]. Low values of $A_{M}$ indicate arid conditions, whereas higher values are associated with increasingly mesic environments.

\section{Analyses}

We performed regression analyses to investigate relationships between antimicrobial protein concentrations of eggs and climatic variables. First, we tested whether we needed to take into account potential non-independence among species due to common ancestry. To do this we calculated mean values (based on mean values per nest) for each population (i.e. per species per location; Table 4). We then used a phylogenetic generalised least squares (pgls) approach [72] to simultaneously estimate maximum likelihood values of the parameter $\lambda$ and test for phylogenetic signal in the model residuals (Pagel's lambda) [73]. A value of $\lambda=0$ indicates no phylogenetic signal, whereas $\lambda=1$ suggests that trait evolution is consistent with a strong effect of phylogeny. We based our phylogeny on the recently prepared phylogenetic tree of larks [74]. For the three species with multiple sampled populations we added branches to the tree for each population to create polytomies, with the branch length for each population within a species set to zero (Additional file 3). There was no evidence of phylogenetic signal in any of our datasets ( $\lambda$ never differed significantly from zero) and so we proceeded by constructing a candidate set of general linear mixed models using all the data in our dataset, rather than mean values per nest and per population. First, all predictor

Table 4 Mean antimicrobial protein concentrations and albumen pH for the eggs of nine lark species

\begin{tabular}{|c|c|c|c|}
\hline Species & Lysozyme $\left(\mathrm{mg} \mathrm{ml}^{-1}\right)$ & Ovotransferrin $\left(\mathrm{mg} \mathrm{ml}^{-1}\right)$ & Albumen $\mathrm{pH}$ \\
\hline Hoopoe lark Alaemon alaudipes & $3.03(0.85)$ & $14.67(3.55)$ & $7.6(0.3)$ \\
\hline Black-crowned finchlark Eremopterix nigriceps & $2.72(1.47)$ & $20.38(6.21)$ & $7.8(0.5)$ \\
\hline Crested lark Galerida cristata & 3.66 & 5.46 & 8.5 \\
\hline \multirow[t]{2}{*}{ Red-capped lark Calandrella cinerea } & $3.39(0.60)$ & $12.57(2.26)$ & $8.2(0.3)$ \\
\hline & 1.73 & 10.27 & 6.7 \\
\hline \multirow[t]{3}{*}{ Horned lark Eremophila alpestris } & $1.18(0.26)$ & $17.30(2.98)$ & $6.8(0.1)$ \\
\hline & $1.08(0.39)$ & $21.32(5.60)$ & $7.0(0.3)$ \\
\hline & 0.98 & 12.02 & 7.9 \\
\hline \multirow[t]{3}{*}{ Hume's short-toed lark Calandrella acutirostris } & $1.24(0.39)$ & $15.69(0.97)$ & $6.8(0.2)$ \\
\hline & $0.88(0.32)$ & $25.45(3.09)$ & $6.9(0.1)$ \\
\hline & 1.43 & 15.80 & 7.9 \\
\hline Oriental skylark Alauda gulgula & 2.09 & 8.34 & 9.4 \\
\hline Skylark Alauda arvensis & $1.22(0.35)$ & $14.61(1.76)$ & $7.8(0.1)$ \\
\hline Woodlark Lullula arborea & $1.63(0.28)$ & $15.83(2.04)$ & $7.9(0.2)$ \\
\hline
\end{tabular}

The values are calculated from mean values per nest for each population, with standard errors (where appropriate) shown in brackets. 
variables were converted to standardized (z) scores, to take account of the fact that different variables were measured on different scales [50]. Models included single and combinations of the fixed effects mean precipitation, mean ambient temperature, the interaction of precipitation and temperature, $\mathrm{A}_{\mathrm{M}}$, and egg albumen $\mathrm{pH}$, and with nest of origin nested within population as random effects. We determined the relative strength of support for each model by calculating Akaike's Information Criterion corrected for small sample sizes $\left(\mathrm{AIC}_{\mathrm{c}}\right)$ and $\mathrm{AIC}_{\mathrm{c}}$ model weights [75]. Model averaging was used to derive parameter estimates and standard errors. We also calculated the relative importance of each explanatory variable and associated $95 \%$ confidence intervals by summing the Akaike weights over all models in which the variable appeared [75]. All analyses were conducted using R, version 2.15.2 [76], with packages caper (pgls [77]), lme4 (model generation [78]), arm (variable standardisation [79]), and MuMIn (model selection and model averaging [80]).

\section{Additional files}

\section{Additional file 1: Information on clutch size and onset of incubation in the lark species in this study.}

Additional file 2: Additional methods and analysis details for measurement of lysozyme activity in albumen.

Additional file 3: Phylogenetic tree illustrating the relationships between the species examined in this study.

\section{Competing interests}

The authors declare that they have no competing interests.

\section{Authors' contributions}

$\mathrm{NPCH}$ and BIT conceived the study. NPCH and $\mathrm{KH}$ conducted the protein concentration assays with the assistance of KDM. NPCH performed the statistical analyses. NPCH wrote the manuscript with the help of BIT and KDM. All authors assisted with obtaining samples. All authors read and approved the final manuscript.

\section{Acknowledgements \\ We thank the following people and organisations for logistical support, and for permission to collect eggs: HH Prince Bandar bin Saud, the President of the Saudi Wildlife Commission and Mr Ahmad Al Bouq, Director of the National Wildlife Research Center, Saudi Arabia; Henk-Jan Ottens and Staatsbosbeheer, Netherlands; Muchai Muchane and National Museums Kenya. Sample collection in Afghanistan was made possible by the generous support of the American people through the United States Agency for International Development (USAID) and its collaborative grantee the Wildlife Conservation Society (WCS). Dieter Lukas and Rose Thorogood helped with phylogenetic analyses. Comments from Steve Beissinger and two anonymous reviewers greatly improved the final manuscript. Financial support came from the Schure-Beijerinck-Poppings Fonds to $\mathrm{NPCH}$ and $\mathrm{AH}$, BirdLife Netherlands to BIT, and VENI and VIDI grants from the Netherlands Organisation for Scientific Research to KDM and BIT.}

\section{Author details}

'Animal Ecology Group, Centre for Ecological \& Evolutionary Studies, University of Groningen, P.O. Box 11103, 9700 CC Groningen, The Netherlands. ${ }^{2}$ Department of Zoology, University of Cambridge, Downing Street, CB2 3EJ Cambridge, UK. ${ }^{3}$ Department of Ornithology, National Museums of Kenya, PO Box 40658, Nairobi, Kenya. ${ }^{4}$ Biology Department, Science College, Taif University, P.O. Box 888, 21974 Taif, Saudi Arabia. ${ }^{5}$ Wildlife Conservation Society, 2300
Southern Boulevard, 10460 Bronx, NY, USA. ${ }^{6}$ Department of Evolution, Ecology \& Organismal Biology, Ohio State University, 43210 Columbus, OH, USA.

Received: 22 January 2014 Accepted: 21 June 2014

Published: 2 July 2014

\section{References}

1. Baggott GK, Graeme-Cook K: Microbiology of natural incubation. In Avian incubation behaviour, environment, and evolution. Edited by Deeming DC. Oxford: Oxford University Press; 2001:638-646.

2. Beissinger SR, Cook Ml, Arendt WJ: The shelf life of bird eggs: testing egg viability using a tropical climate gradient. Ecology 2005, 86:2164-2175.

3. Cook MI, Beissinger SR, Toranzos GA, Rodriguez RA, Arendt WJ: Trans-shell infection by pathogenic micro-organisms reduces the shelf life of non-incubated bird's eggs: a constraint on the onset of incubation? Proc R Soc B 2003, 270:2233-2240.

4. Cook Ml, Beissinger SR, Toranzos GA, Arendt WJ: Incubation reduces microbial growth on eggshells and the opportunity for trans-shell infection. Ecol Lett 2005, 8:532-537.

5. Cook MI, Beissinger SR, Toranzos GA, Rodriguez RA, Arendt WJ: Microbial infection affects egg viability and incubation behavior in a tropical passerine. Behav Ecol 2005, 16:30-36.

6. Wang JM, Firestone MK, Beissinger SR: Microbial and environmental effects on avian egg viability: do tropical mechanisms act in a temperate environment? Ecology 2011, 92:1137-1145.

7. Field CB, Behrenfeld MJ, Randerson JT, Falkowski P: Primary production of the biosphere: integrating terrestrial and oceanic components. Science 1998, 281:237-240.

8. Fierer N, Jackson RB: The diversity and biogeography of soil bacterial communities. Proc Natl Acad Sci U S A 2006, 103:626-631.

9. Chu H, Fierer N, Lauber CL, Caporaso JG, Knight R, Grogan P: Soil bacterial diversity in the Arctic is not fundamentally different from that found in other biomes. Environ Microbiol 2010, 12:2998-3006.

10. Bachar A, Al-Ashhab A, Soares M, Sklarz M, Angel R, Ungar E, Gillor O: Soil microbial abundance and diversity along a low precipitation gradient. Microb Ecol 2010, 60:453-461.

11. Drenovsky RE, Steenwerth KL, Jackson LE, Scow KM: Land use and climatic factors structure regional patterns in soil microbial communities. Global Ecol Biogeogr 2010, 19:27-39.

12. Blankinship JC, Niklaus PA, Hungate BA: A meta-analysis of responses of soil biota to global change. Oecologia 2011, 165:553-565.

13. Pasternak Z, Al-Ashhab A, Gatica J, Gafny R, Avraham S, Minz D, Gillor O, Jurkevitch E: Spatial and temporal biogeography of soil microbial communities in arid and semiarid regions. PLoS One 2013, 8:e69705.

14. Serna-Chavez HM, Fierer N, van Bodegom PM: Global drivers and patterns of microbial abundance in soil. Global Ecol Biogeogr 2013, 22:1162-1172.

15. Shawkey MD, Mills KL, Dale C, Hill GE: Microbial diversity of wild bird feathers revealed through culture-based and culture-independent techniques. Microb Ecol 2005, 50:40-47.

16. Potter BA, Carlson BM, Adams AE, Voss MA: An assessment of the microbial diversity present on the surface of naturally incubated House Wren eggs. Open Ornithol J 2013, 6:32-39.

17. Ruiz-de-Castañeda R, Vela Al, Lobato E, Briones V, Moreno J: Prevalence of potentially pathogenic culturable bacteria on eggshells and in cloacae of female Pied Flycatchers in a temperate habitat in central Spain. J Field Ornithol 2011, 82:215-224.

18. Berger S, Disko R, Gwinner H: Bacteria in starling nests. J Ornithol 2003, 144:317-322.

19. Horrocks NPC, Hegemann A, Matson KD, Hine K, Jaquier S, Shobrak M, Williams JB, Tinbergen JM, Tieleman BI: Immune indexes of larks from desert and temperate regions show weak associations with life history but stronger links to environmental variation in microbial abundance. Physiol Biochem Zool 2012, 85:504-515.

20. D'Alba L, Oborn A, Shawkey M: Experimental evidence that keeping eggs dry is a mechanism for the antimicrobial effects of avian incubation. Naturwissenschaften 2010, 97:1089-1095.

21. Shawkey MD, Firestone MK, Brodie EL, Beissinger SR: Avian incubation inhibits growth and diversification of bacterial assemblages on eggs. PLoS One 2009, 4:e4522. 
22. Ruiz-De-Castañeda R, Vela Al, González-Braojosa S, Briones V, Moreno J: Drying eggs to inhibit bacteria: Incubation during laying in a cavity nesting passerine. Behav Process 2011, 88:142-148.

23. Board RG, Halls NA: The cuticle: a barrier to liquid and particle penetration of the shell of the hen's egg. Br Poultry Sci 1973, 14:69-97.

24. Board RG, Loseby S, Miles VR: A note on microbial growth on eggshells. Br Poultry Sci 1979, 20:413-420.

25. Burrows SM, Elbert W, Lawrence MG, Poschl U: Bacteria in the global atmosphere - Part 1: review and synthesis of literature data for different ecosystems. Atmos Chem Phys 2009, 9:9263-9280.

26. Tang JW: The effect of environmental parameters on the survival of airborne infectious agents. J $R$ Soc Interface 2009, 6:S737-S746.

27. Tong $Y$, Lighthart B: Solar radiation has a lethal effect on natural populations of culturable outdoor atmospheric bacteria. Atmos Environ 1997, 31:897-900.

28. Saranathan V, Burtt EH Jr: Sunlight on feathers inhibits feather-degrading bacteria. Wilson J Ornithol 2007, 119:239-245.

29. Board RG, Fuller R: Nonspecific antimicrobial defences of avian egg, embryo and neonate. Biol Rev Camb Philos Soc 1974, 49:15-49.

30. Réhault-Godbert S, Hervé-Grépinet V, Gautron J, Cabau C, Nys Y, Hincke $\mathrm{M}$ : Molecules involved in chemical defence of the chicken egg. In Improving the Safety and Quality of Eggs and Egg Products. Edited by Nys Y, Bain M, Van Immerseel F. Philadelphia: Woodhead Publishing; 2011:183-208.

31. Gasparini J, McCoy KD, Haussy C, Tveraa T, Boulinier T: Induced maternal response to the Lyme disease spirochaete Borrelia burgdorferi sensu lato in a colonial seabird, the kittiwake Rissa tridactyla. Proc $R$ Soc B 2001 268:647-650.

32. Grindstaff JL, Hasselquist D, Nilsson JA, Sandell M, Smith HG, Stjernman M: Trans-generational priming of immunity: maternal exposure to a bacterial antigen enhances offspring humoral immunity. Proc $R$ SOC $B$ 2006, 273:2551-2557.

33. Saino N, Dall'ara P, Martinelli R, Møller AP: Early maternal effects and antibacterial immune factors in the eggs, nestlings and adults of the barn swallow. J Evol Biol 2002, 15:735-743.

34. Millet S, Bennett J, Lee KA, Hau M, Klasing KC: Quantifying and comparing constitutive immunity across avian species. Dev Comp Immunol 2007, 31:188-201.

35. Xie H, Huff GR, Huff WE, Balog JM, Holt P, Rath NC: Identification of ovotransferrin as an acute phase protein in chickens. Poult Sci 2002, 81:112-120.

36. Shawkey MD, Kosciuch KL, Liu M, Rohwer FC, Loos ER, Wang JM, Beissinger SR: Do birds differentially distribute antimicrobial proteins within clutches of eggs? Behav Ecol 2008, 19:920-927.

37. Wellman-Labadie O, Picman J, Hincke MT: Enhanced C-type lysozyme content of Wood Duck (Aix sponsa) egg white: an adaptation to cavity nesting? Physiol Biochem Zool 2008, 81:235-245

38. D'Alba L, Shawkey MD, Korsten P, Vedder O, Kingma SA, Komdeur J, Beissinger SR: Differential deposition of antimicrobial proteins in blue tit (Cyanistes caeruleus) clutches by laying order and male attractiveness. Behav Ecol Sociobiol 2010, 64:1037-1045.

39. Bedrani L, Helloin E, Guyot N, Réhault-Godbert S, Nys Y: Passive maternal exposure to environmental microbes selectively modulates the innate defences of chicken egg white by increasing some of its antibacterial activities. BMC Microbiol 2013, 13:128.

40. Horrocks NPC, Matson KD, Tieleman BI: Pathogen pressure puts immune defense into perspective. Integr Comp Biol 2011, 51:563-576.

41. Tieleman Bl: Physiological, behavioral and life history adaptations of larks along an aridity gradient: a review. In Ecology and Conservation of Steppe-Land Birds. Edited by Bota G, Camprodon J, Manosa S, Morales M. Barcelona: Lynx Edicions; 2005:49-67.

42. Tieleman Bl, Williams JB, Bloomer P: Adaptation of metabolism and evaporative water loss along an aridity gradient. Proc $R$ Soc $B$ 2003, 270:207-214.

43. Tieleman BI, Williams JB, Visser GH: Energy and water budgets of larks in a life history perspective: parental effort varies with aridity. Ecology 2004, 85:1399-1410.

44. Godard RD, Wilson CM, Frick JW, Siegel PB, Bowers BB: The effects of exposure and microbes on hatchability of eggs in open-cup and cavity nests. J Avian Biol 2007, 38:709-716
45. Peralta-Sánchez JM, Martín-Vivaldi M, Martín-Platero AM, Martínez-Bueno M, Oñate M, Ruiz-Rodríguez M, Soler JJ: Avian life history traits influence eggshell bacterial loads: a comparative analysis. Ibis 2012, 4:725-737.

46. Burley RW, Vadehra DV: The Avian Egg: Chemistry and Biology. New York: Wiley; 1989

47. Callewaert L, Michiels C: Lysozymes in the animal kingdom. J Biosci 2010, 35:127-160

48. Superti F, Ammendolia MG, Berlutti F, Valenti P: Ovotransferrin. In Bioactive Egg Compounds. Edited by Huopalahti R, López-Fandiño R, Anton M, Schade R. Berlin \& Heidelberg: Springer; 2007:43-50.

49. Tranter HS, Board RG: The influence of incubation temperature and $\mathrm{pH}$ on the antimicrobial properties of hen egg albumen. J Appl Microbio/ 1984, 56:53-61.

50. Gelman A: Scaling regression inputs by dividing by two standard deviations. Stat Med 2008, 27:2865-2873.

51. Ruiz-de-Castañeda R, Vela Al, Lobato E, Briones V, Moreno J: Bacterial loads on eggshells of the Pied Flycatcher: environmental and maternal factors. Condor 2011, 113:200-208.

52. Ratkowsky DA, Lowry RK, McMeekin TA, Stokes AN, Chandler RE: Model for bacterial culture growth rate throughout the entire biokinetic temperature range. J Bacterio/ 1983, 154:1222-1226.

53. Saino $N$, Romano M, Ambrosini R, Ferrari RP, Møller AP: Timing of reproduction and egg quality covary with temperature in the insectivorous Barn Swallow, Hirundo rustica. Funct Ecol 2004, 18:50-57.

54. Cucco M, Guasco B, Ottonelli R, Balbo V, Malacarne G: The influence of temperature on egg composition in the grey partridge Perdix perdix. Ethol Ecol Evol 2009, 21:63-77.

55. Kato A, Imoto T, Yagishita K: The binding groups in ovomucin-lysozyme interaction. Agri Biol Chem 1975, 39:541-544.

56. Robinson DS, Monsey JB: Change in the composition of ovomucin during liquefaction of thick egg white. J Sci Food Agric 1972, 23:29-38.

57. Hurnik Gl, Reinhart BS, Hurnik JF: Relationship between albumen quality and hatchability in fresh and stored hatching eggs. Poult Sci 1978, 57:854-857.

58. Reijrink IAM, Meijerhof R, Kemp B, Van Den Brand H: The chicken embryo and its micro environment during egg storage and early incubation. World Poultry Sci J 2008, 64:581-598.

59. Ko KY, Mendoncam AF, Ismail H, Ahn DU: Ethylenediaminetetraacetate and lysozyme improves antimicrobial activities of ovotransferrin against Escherichia coli 0157:H7. Poult Sci 2009, 88:406-414.

60. Board RG, Tranter HS: The microbiology of eggs. In Egg Science \& Technology. 3rd edition. Edited by Stadelman WJ, Cotterill OJ. Westport CT: AVI Publishing Co; 1986:75-96.

61. Sellier N, Vidal ML, Baron F, Michel J, Gautron J, Protais M, Beaumont C, Gautier M, Nys Y: Estimations of repeatability and heritability of egg albumen antimicrobial activity and of lysozyme and ovotransferrin concentrations. Brit Poultry Sci 2007, 48:559-566.

62. Bedrani L, Helloin E, Guyot N, Nys Y: Systemic administration of lipopolysaccharide in laying hens stimulates antimicrobial properties of egg white against Staphylococcus aureus. Vet Immunol Immunop 2013, 152:225-236.

63. Grizard S, Dini-Andreote F, Tieleman BI, Salles JF: Dynamics of bacterial and fungal communities associated with eggshells during incubation. Ecol Evol 2014, doi: 10.1002/ece3.1011.

64. Soler JJ, Peralta-Sánchez JM, Martín-Platero AM, Martín-Vivaldi M, Martínez-Bueno M, Møller AP: The evolution of size of the uropygial gland: mutualistic feather mites and uropygial secretion reduce bacterial loads of eggshells and hatching failures of European birds. J Evol Biol 2012, 25:1779-1791.

65. Lozupone CA, Knight R: Global patterns in bacterial diversity. Proc Natl Acad Sci U S A 2007, 104:11436-11440.

66. Del Hoyo J, Elliott A, Christie DA: Cotingas to Pipits and Wagtails. In Handbook of the Birds of the World. 9th edition. Barcelona: Lynx Edicions; 2004.

67. Google Earth 7.1.2.2041: Google Earth 7.1.2.2041; 2014. http://www.google. com/earth/index.html (Accessed 28/04/2014).

68. Horrocks NPC, Tieleman BI, Matson KD: A simple assay for measurement of ovotransferrin - a marker of inflammation and infection in birds. Methods Ecol Evol 2011, 2:518-526.

69. Harris I, Jones PD, Osborn TJ, Lister DH: Updated high-resolution grids of monthly climatic observations. Int J Climatol 2014, 34:623-642. 
70. Horrocks NPC, Matson KD, Shobrak M, Tinbergen JM, Tieleman BI: Seasonal patterns in immune indices reflect microbial loads on birds but not microbes in the wider environment. Ecosphere 2012, 3:art:19.

71. de Martonne E: Une nouvelle fonction climatologique: $L^{\prime}$ indice d'aridité. La Météorologie 1926, 2:449-458.

72. Freckleton RP, Harvey PH, Pagel M: Phylogenetic analysis and comparative data: a test and review of evidence. Am Nat 2002, 160:712-726.

73. Pagel M: Inferring the historical patterns of biological evolution. Nature 1999, 401:877-884

74. Alström P, Barnes KN, Olsson U, Barker FK, Bloomer P, Khan AA, Qureshi MA, Guillaumet A, Crochet P-A, Ryan PG: Multilocus phylogeny of the avian family Alaudidae (larks) reveals complex morphological evolution, non-monophyletic genera and hidden species diversity. Mol Phylogenet Evol 2013, 69:1043-1056.

75. Burnham KP, Anderson DR: Model selection and mulitmodel inference: $A$ practical information-theoretic approach. New York: Springer Verlag; 2002.

76. R Core Team: $R$ : A language and environment for statistical computing. Vienna, Austria: R Foundation for Statistical Computing; 2012. http://www.R-project.org/.

77. Orme D, Freckleton R, Thomas G, Petzoldt T, Fritz S, Isaac N, Pearse W: caper: Comparative Analyses of Phlogenetics and Evolution in R. In $R$ package version 0.5.2; 2013. http://CRAN.R-project.org/package=caper.

78. Bates D, Maechler M, Bolker B, Walker S: Ime4: Linear mixed-effects models using Eigen and S4. In R package version 1.0-5; 2013. http://CRAN.R-project. org/package=Ime4

79. Gelman A, Su Y-S: arm: Data analysis using regression and multilevel/ hierarchical models. In $R$ package version 1.6-10; 2013. http://CRAN.Rproject.org/package $=$ arm.

80. Bartoń K, UMIn: Multi-model inference. In R package version 1.9.13; 2013. http://CRAN.R-project.org/package=MuMIn.

doi:10.1186/1742-9994-11-49

Cite this article as: Horrocks et al:: Are antimicrobial defences in bird eggs related to climatic conditions associated with risk of trans-shell microbial infection?. Frontiers in Zoology 2014 11:49.

\section{Submit your next manuscript to BioMed Central and take full advantage of:}

- Convenient online submission

- Thorough peer review

- No space constraints or color figure charges

- Immediate publication on acceptance

- Inclusion in PubMed, CAS, Scopus and Google Scholar

- Research which is freely available for redistribution 